\title{
Effects of the Alpha-Health intervention on elderly's health literacy in primary health care
}

\author{
Efeitos da intervenção Alfa-Saúde na alfabetização em saúde do idoso na atenção primária à saúde
}

Efectos de la intervención Alfa-Salud en la alfabetización sanitaria de los ancianos en la atención primaria de salud

'Universidade Federal de Alagoas. Arapiraca, Alagoas, Brazil.

"Universidade Franciscana. Santa Maria, Rio Grande do Sul, Brazil.

I' Universidade Federal do Rio Grande do Sul. Porto Alegre,

Rio Grande do Sul, Brazil.

How to cite this article:

Serbim AK, Santos NO, Paskulin LMG. Effects of the Alpha-

Health intervention on elderly's health literacy in primary

health care. Rev Bras Enferm. 2022;75(Suppl 4):e20200978.

https://doi.org/10.1590/0034-7167-2020-0978

Corresponding author:

Andreivna Kharenine Serbim

E-mail: andreivna.serbim@arapiraca.ufal.br

EDITOR IN CHIEF: Dulce Barbosa

ASSOCIATE EDITOR: Fátima Helena do Espírito Santo

Submission: 09-11-2020 Approval: 10-08-2021

\begin{abstract}
Objective: to assess the effects of the Alpha-Health intervention on health literacy and health habits of elderly people linked to primary care, when compared to usual health care. Methods: a quasi-experimental investigation, with mixed methods, with 21 elderly individuals in each group. Alpha-Health was performed by a nurse for five months. The Short Assessment of Health Literacy for Portuguese Speaking Adults, Health Literacy and questions about health habits were used. In the quantitative analysis, the GEE Model was used, and in the qualitative, thematic analysis. Results: there was an interaction effect on health literacy scores. Health habits such as vaccination, three meals a day and meat consumption had a statistically significant interaction effect. In the qualitative stage, development in skills of accessing, communicating and assessing information was observed as well as stability in the ability to understand. Conclusions: AlphaHealth is an important device for developing elderly's health literacy.

Descriptors: Health Literacy; Health; Elderly; Health Education; Primary Health Care.
\end{abstract}

\section{RESUMO}

Objetivo: avaliar os efeitos da intervenção Alfa-Saúde na alfabetização em saúde e hábitos de saúde de idosos vinculados à atenção primária, quando comparada ao atendimento de saúde usual. Métodos: investigação quase-experimental, com métodos mistos, com 21 idosos em cada grupo. O Alfa-Saúde foi realizado por enfermeira durante cinco meses. Instrumentos utilizados foram o Short Assessment of Health Literacy for Portuguese Speaking Adults, Health Literacy e perguntas sobre hábitos de saúde. Na análise quantitativa, foi utilizado o GEE Model, e na qualitativa, análise temática. Resultados: houve efeito de interação nos escores da alfabetização em saúde. Hábitos de saúde, como vacinação, três refeições diárias e consumo de carne, apresentaram efeito de interação com significância estatística. Na etapa qualitativa, observou-se o desenvolvimento nas habilidades de acessar, comunicar e avaliar a informação, e estabilidade na habilidade de compreensão. Conclusões: o Alfa-Saúde é um dispositivo importante para o desenvolvimento da alfabetização em saúde de idosos. Descritores: Letramento em Saúde; Saúde; Idoso; Educação em Saúde; Atenção Primária à Saúde.

\section{RESUMEN}

Objetivo: evaluar los efectos de la intervención Alfa-Salud sobre la alfabetización sanitaria y los hábitos de salud de los ancianos vinculados a la atención primaria, en comparación con la atención sanitaria habitual. Métodos: investigación cuasiexperimental, con métodos mixtos, con 21 ancianos en cada grupo. El Alfa-Salud fue realizado por una enfermera durante cinco meses. Los instrumentos utilizados fueron la Short Assessment of Health Literacy for Portuguese Speaking Adults, Health Literacy y preguntas sobre hábitos de salud. En el análisis cuantitativo se utilizó el Modelo GEE y en el análisis cualitativo temático. Resultados: hubo un efecto de interacción en los puntajes de alfabetización en salud. Los hábitos de salud como la vacunación, las tres comidas al día y el consumo de carne mostraron un efecto de interacción estadísticamente significativo. En la etapa cualitativa, hubo un desarrollo en las habilidades para acceder, comunicar y evaluar la información, y estabilidad en la capacidad de comprensión. Conclusiones: el Alfa-Salud es un dispositivo importante para el desarrollo de la alfabetización en salud para las personas mayores.

Descriptores: Alfabetización en Salud; Salud; Anciano; Educación en Salud; Atención Primaria de Salud. 


\section{INTRODUCTION}

Health literacy has been considered a priority to reduce health inequalities ${ }^{(1)}$, through access to information and the ability to use it effectively, contributing to people's empowerment ${ }^{(2)}$. The scientific literature presents different concepts about it ${ }^{(2-3)}$. In the present study, it is defined as the degree to which people are able to access, understand, communicate and assess health information in order to maintain and promote health throughout life within different contex $t^{(4)}$. The development of these health literacy skills can be considered a positive result of health education activities.

Some population groups may have low levels of health literacy, such as those made up of elderly people and, especially, those with low income and low education ${ }^{(5)}$. Moreover, they have great difficulty in performing self-care in the presence of chronic diseases, have high rates of hospital admissions and use of emergency services, in addition to early mortality ${ }^{(6-8)}$.

To date, no population studies have been published in Brazil on health literacy. Brazilian studies are still scarce and assessed the general population's health literacy ${ }^{(9)}$, adults with a high level of education ${ }^{(10)}$ and adults with and without hypertension ${ }^{(11)}$. Studies with elderly people were carried out in the community ${ }^{(12)}$ and in the clinical/outpatient context ${ }^{(13-14)}$.

Primary health care $(\mathrm{PHC})$ is the ideal place to promote health and develop interventions that are accessible to the community. A recent study protocol ${ }^{(15)}$ released an intervention to promote health literacy with elderly people from 16 health units in primary care in Spain.

One of the important outcomes for assessing health promotion actions is health literacy ${ }^{(2)}$. It appears that the studies that developed educational interventions with the elderly had positive results and, for the most part, addressed the digital context, and were directed towards people with better socioeconomic conditions ${ }^{(16)}$.

There is, however, a gap in knowledge regarding the effects that an educational intervention, developed for vulnerable elderly people from a socioeconomic point of view, could develop on the health literacy of elderly people in a community. In this context, the educational intervention called Alpha-Health was developed, originated from a doctoral thesis and offered by a nurse in primary care. The activity aimed to promote elderly's health literacy, assessing an intervention model that could be replicated by nurses in PHC. Based on these considerations, this study seeks to answer the following research question: what are the effects of the AlphaHealth intervention on health literacy and health habits of vulnerable elderly linked to primary care, when compared to the usual health care for the elderly?

\section{OBJECTIVE}

To assess the effects of the Alpha-Health intervention on health literacy and health habits of elderly people linked to primary care, when compared to usual health care.

\section{METHODS}

\section{Ethical aspects}

The study was approved by the Institutional Review Board of the Universidade Federal do Rio Grande do Sul (UFRGS), CAAE
(Certificado de Apresentação para Apreciação Ética - Certificate of Presentation for Ethical Consideration).

\section{Design, place, and period}

It is a quasi-experimental investigation, with a mixed methods approach by concomitant triangulation. The research followed the recommendations of the Transparent Reporting of Evaluations with Nonrandomized Designs (TREND) of the Centers for Disease Control and Prevention (CDC) ${ }^{(17)}$.

The study was carried out in two primary care health units in the city of Arapiraca, Alagoas, northeastern Brazil, with an estimated population of 230,417 inhabitants and a Municipal Human Development Index (MHDI) of $0.649^{(18)}$. Data collection and intervention were carried out between September 2017 and July 2018.

\section{Selection criteria}

The inclusion criteria for defining the health units were: not having a group of elderly people on the health unit premises; having physical space to carry out the intervention; and not being the health units close to each other. Of 40 health units in the municipality, ten met the criteria and two were intentionally chosen, one being designated to carry out the intervention.

\section{Sample: inclusion and exclusion criteria}

The study participants were elderly users registered in the two health units chosen. The inclusion criteria were: declare to know how to read; be able to move to the reference health unit; and be available to participate in the intervention once a week for a period of five months. Exclusion criteria were: declare themselves unable to answer the interview, because they presented hearing or vision problems; have indication of cognitive deficit (score < 6 in the 10 point cognitive screener) ${ }^{(19)}$; and participate in some group in local health services.

The sample calculation was based on the validation study of the instruments Short Assessment of Health Literacy for Portuguese Speaking Adults (SALHPA- 50) and the brief version, SAHLPA-18 ${ }^{(13)}$, using Winpepi V.11.44. The mean score of 37.7 points and a standard deviation of \pm 9.0 were considered, with a sample of 226 elderly individuals when using the SAHLPA-50 in the validation study. With a power of $80 \%$ and a significance level of 0.05 , considering a unit standard deviation and expecting a difference of one (01) standard deviation between the groups, the calculated sample was 34 elderly individuals. Adding $20 \%$ of losses, the final sample was 42 elderly individuals, with 21 elderly individuals in the Intervention Group (IG) and 21 in the Comparison Group (CG).

\section{Study protocol}

For each health unit, a list was constructed with elderly's names in alphabetical order, address and telephone number for contact obtained through the individual e-SUS PHC registration. The first researcher contacted the elderly by telephone or in person and assessed inclusion and exclusion criteria of participants. 
This approach was performed until the number of participants needed for IG and CG was completed. The interviews lasted approximately 60 minutes and were conducted in the facilities of the health units.

Age, sex, marital status, education, income and with whom the elderly lived were collected. To detect health literacy quantitatively, the adapted and validated instrument SAHLPA-18, of 18 terms, which assesses the pronunciation and understanding of health terms ${ }^{(13)}$, was used. The application provides for the presence of an interviewer who uses cards with a term printed in bold at the top and with two association words at the bottom. The interviewees were asked to read aloud the term in bold. The interviewer read the two words of the association and asked which one was associated with the term ${ }^{(14)}$. Each correct term (reading and association) corresponded to 1 point with a maximum score of 18 . After that, the interviewees were classified as having inadequate health literacy (1-14 points) or adequate health literacy (15-18 points) ${ }^{(13)}$.

In the qualitative stage, the Health Literacy instrument was used, built in Canada and adapted for use in Brazil, composed of open-ended and closed-ended questions ${ }^{(4,20)}$. The interview starts with a question about an interest or concern in health experienced and chosen by participants, who answers the other questions based on a specific health situation ("In the last month, what did you think about your health?"). Next, questions about this health situation, the sources of information used related to the situation, understanding, sharing and impact of the information accessed on individuals' health ${ }^{(20)}$ are asked. The questions that make up the Health Literacy instrument are organized based on health literacy skills (access, understand, communicate and assess health information).

Some variables from the Caderneta de Saúde da Pessoa Idosa (21) were also used as outcomes, such as health habits and vaccination schedule (influenza, diphtheria-tetanus and hepatitis B).

The Alpha-Health intervention ${ }^{(22)}$ lasted for five months (20 weeks) and was conducted by a nurse in an IG health unit in a space to develop groups. Each meeting lasted 1 hour and 30 minutes. The intervention was structured based on health literacy skills: accessing/searching for health information (finding health information and necessary health services); understanding health information (working on understanding different themes)); communicating health information (developing the confidence to share health information with professionals, family and friends); and assessing health information (identifying reliable sources of information in the health system and on the internet). In all meetings, these skills were worked, using devices that arouse elderly's interest and reflection, such as videos, workshops, games, dynamics, exhibition and discussion of themes, printed material, figures and a visit to an elder association.

The themes addressed, which had as reference the Active Aging Policy ${ }^{(23)}$, were: use of the health services network; use and storage of medications; healthy eating; healthy habits; oral health; mental health; falls; physical activity; men's and women's health; sexuality; human rights; elderly's rights; work and retirement; abuse and violence; popular participation; and healthy environments. At the end of the intervention, the elderly were interviewed in the same way they were at baseline.

\section{Analysis of results, and statistics}

Descriptive and inferential analyses were performed in SPSS v.25. The GEE Model was used to compare groups, times, and interaction (group*time) ${ }^{(24)}$. For binary variables, the binomial distribution with logit link function was used. For continuous variables, the normal distribution with identity link function was used. The model was constructed using an independent working correlation matrix and a robust estimator covariance matrix. The post-hoc test used was Bonferroni's. The significance level established was 5\%.

For the organization of qualitative data, qualitative solutions research Nvivo (QSR NVivo), version 11.0, was used. The interviews were transcribed and analyzed through thematic analysis ${ }^{(25)}$, using as categories the questions that make up the Health Literacy instrument. These categories gave rise to the themes that emerged and were used for comparison at baseline and follow-up and for the comparison of data between the IG and CG.

Quantitative and qualitative data triangulation occurred during the interpretation and analysis of results, seeking to understand the divergences and similarities between the findings ${ }^{(26)}$. In the present study, the qualitative stage had a greater weight than the quantitative stage.

\section{RESULTS}

Table 1 shows elderly's sociodemographic characteristics at the baseline of the study, presenting data from the 21 elderly individuals from the CG and IG. This table demonstrates that the $p$-values were not statistically significant and that the groups were similar. In the CG, there were six losses (one participant gave up; three participants moved; two participants were not found). In the IG, there were eight losses during the educational intervention (five participants gave up; two participants moved; one participant was injured). Therefore, in the follow-up interviews, there were 13 elderly individuals in the IG and 15 in the CG.

Table 1 - Elderly's sociodemographic characteristics at baseline, Arapiraca, Alagoas, Brazil, 2017

\begin{tabular}{lccc}
\hline & *CG (n=21) & +IG (n=21) & $\boldsymbol{p}$ \\
\hline Age & & & \\
$\quad 60-69$ & $19 \%$ & $71.4 \%$ & 0.726 \\
$70-79$ & - & $23.8 \%$ & \\
$\quad 80$ and older & $4.8 \%$ & \\
Sex & $76.2 \%$ & $66.7 \%$ & 0.734 \\
$\quad$ Female & & & \\
$\quad$ Marital status & $61.9 \%$ & $47.6 \%$ & 0.501 \\
$\quad$ Without a partner & & & \\
With whom does the elderly live? & \\
$\quad$ Spouse & $11(36.7)$ & $8(22.9)$ & \\
$\quad$ Grandchild & $7(23.3)$ & $9(25.7)$ & \\
$\quad$ Child & $6(20)$ & $8(22.9)$ & \\
$\quad$ Alone & $5(16.7)$ & $5(14.3)$ & \\
$\quad$ Others & $1(3.3)$ & $5(14.3)$ & \\
Cognitive assessment & $7[6 ; 8]$ & $7[6 ; 8]$ & 0.517 \\
Study years & $4[1 ; 5]$ & $4[2 ; 5]$ & 0.899 \\
$\quad$ Number of minimum wages $^{\S}$ & $1[1 ; 1]$ & $1[1 ; 2]$ & 0.680 \\
\hline
\end{tabular}

Categorical variables were expressed, as relative frequency and continuous variables, by median and interquartile interval [q1; q3], for those with asymmetric distribution.

${ }^{*} \mathrm{CG}=$ Comparison Group; $+I G=$ Intervention Group; $¥$ Multiple response: $C G(30) ; I G(35) ; \S C$ Current minimum wage $=R \$ 937.00$ (about US\$170.36), Brazil, 2017. 
Regarding the interaction effect on the mean of SAHLPA, when comparing the baseline and follow-up, it is verified that health literacy scores increased in both groups, from 10.9 to 11.5 in the CG and from 10.7 to 12.7 in the IG, but without statistical significance. The proportion of elderly people classified as having adequate health literacy also increased in both groups, with a greater difference in the IG (from $23.8 \%$ to $38.5 \%$ ), without statistical significance.

Regarding the comparison of the proportions of health habits between groups and times and the interaction effect, there were statistically significant changes $(p \leq 0.001)$ in having three meals a day at baseline (mean=79.5; - Cl 95\%: [64.1; 89.4]) and follow-up (mean=100; - 95\% Cl: [100; 100]). Interaction could not be calculated, however, the mean times differed regardless of group, suggesting that this difference is due to the IG. Meat consumption showed statistically significant changes $(\mathrm{p} \leq 0.001)$ at baseline (mean=88.3; 95\% Cl: [74.5; 95.1]) and follow-up (mean $=100 ;-95 \%$ Cl: [100;100]). Regardless of group, the mean showed a difference between times. Fixing time, the mean of meat consumption was different between the groups.

Influenza, hepatitis B and diphtheria-tetanus vaccination rates also showed statistically significant changes $(p \leq 0.001)$ in the proportions at baseline (mean $=69.1 ; 95 \% \mathrm{Cl}$ : $[53.7 ; 81.2])$, (mean $=8.4 ;-95 \% \mathrm{Cl}$ : $[2.7 ; 22.8]),(\operatorname{mean}=23.5 ;-95 \% \mathrm{Cl}:[13 ; 38.7])$ and at follow-up respectively (mean $=100 ;-95 \% \mathrm{Cl}$ : $[100 ; 100])$, (mean=32.8; - 95\% Cl: [12.8; 61.9]), (mean=67.6; - 95\% Cl: [39.3; 87.1]). Regarding influenza vaccine, interaction could not be calculated; however, the mean time differed regardless of group, suggesting that this difference is due to the IG. In hepatitis B and diphtheria-tetanus vaccines, the Bonferroni test was $\leq 0.001$ in both comparisons: when fixing the group and comparing the time, and when fixing the time and comparing the group.

In the other health habits, an increase in the proportion of responses considered positive in the IG was observed, such as baseline leisure activities (mean $=19 ;-95 \% \mathrm{Cl}$ : $[7.3 ; 41.2]$ ) for follow-up (mean=30.8; - 95\% Cl: [12;59.1]), baseline physical activities (mean=28.6; - 95\% Cl: $[13.4 ; 50.8]$ ) to follow-up (mean=61.5; - 95\% Cl: [34.4; 83]), baseline fruit and vegetable consumption (mean $=76.2 ;-95 \% \mathrm{Cl}$ : [54;89.7]) for follow-up (mean=84.6; - 95\% $\mathrm{Cl}$ [ $54.9 ; 96.1])$, baseline water intake $(\operatorname{mean}=61.9 ;-95 \% \mathrm{Cl}$ : [40.4; 79.7]) for follow-up (mean=92.3; - 95\% Cl: [60.9; 98.9]). In the consumption of cake, desserts, oil, sugar and salt, the same decrease in the proportion of responses in IG was observed, as at baseline (mean=61.9; - 95\% Cl: [40.2;79.7]) for the follow-up (mean $=15.4 ;-95 \% \mathrm{Cl}$ : [3.9;45.1]). These results were not statistically significant.

The charts below present the four categories that make up the qualitative stage of the study, i.e., the health literacy ability to seeking/accessing, understanding, sharing and assessing health information. Each chart is divided by the occurrence of themes in the CG and IG, at baseline and follow-up, in addition to the lines that exemplify the themes presented.

In Chart 1, regarding the ability to seeking/accessing health information, it was observed that the main source of information referred was the doctor and that most of the health information received was considered prescriptive.

Chart 2 presents the results of category Ability to understanding health information. It was observed that actions about what the elderly did when they did not understand a medical term did not change at baseline and follow-up in both groups.

Chart 1 - Presentation of themes and examples of participants'statements, referring to category Ability to seeking/accessing health information, at baseline and follow-up, Arapiraca, Alagoas, Brazil, 2018

\begin{tabular}{|c|c|c|c|}
\hline \multicolumn{4}{|c|}{ Category: Ability to seeking/accessing health information } \\
\hline CG* baseline themes & CG* follow-up themes & IGt baseline themes & IGt follow-up themes \\
\hline $\begin{array}{l}1 \text { - Doubts about the chosen } \\
\text { health situation: reported } \\
\text { having doubts about whether } \\
\text { the chosen health situation was } \\
\text { serious; about what was the } \\
\text { health situation; others reported } \\
\text { that they had no doubts or were } \\
\text { not concerned about the chosen } \\
\text { health situation. } \\
\mathbf{2} \text {-Predominant sources of } \\
\text { information: doctor; health unit; } \\
\text { emergency service; television } \\
\text { programs. }\end{array}$ & $\begin{array}{l}1 \text { - Doubts about the } \\
\text { chosen health situation: } \\
\text { similar to the baseline } \\
2 \text {-Predominant sources } \\
\text { of information: similar } \\
\text { to the baseline, but the } \\
\text { emergency service and } \\
\text { television programs were } \\
\text { not mentioned. }\end{array}$ & $\begin{array}{l}1 \text { - Doubts about the chosen } \\
\text { health situation: similar to } \\
\text { the CG baseline, but some IG } \\
\text { participants were unable to } \\
\text { answer this question. } \\
2 \text {-Predominant sources } \\
\text { of information: doctor; } \\
\text { emergency service; people } \\
\text { with the same problem. }\end{array}$ & $\begin{array}{l}1 \text { - Doubts about the chosen health } \\
\text { situation: reported having doubts about } \\
\text { food; about what the health situation } \\
\text { was; about the complexity of the health } \\
\text { situation; others reported that they had no } \\
\text { doubts or were not concerned about the } \\
\text { chosen health situation; some reported } \\
\text { concern in solving the health situation; } \\
\text { worry about being dependent. } \\
\text { 2-Predominant sources of information: } \\
\text { doctor; health unit; Alpha-Health nurse; } \\
\text { people with the same problem. }\end{array}$ \\
\hline \multicolumn{4}{|c|}{ Examples of participants' speeches } \\
\hline $\begin{array}{l}1 \text { - Doubts I didn't have any that } \\
\text { I didn't even know what it was. } \\
\text { (Participant } 20 \text {, female, } 60 \text { years old) } \\
2 \text { - No, the doctor doesn't guide } \\
\text { me, she just gives me the medicine. } \\
\text { (Participant } 15 \text {, female, } 61 \text { years old) }\end{array}$ & $\begin{array}{l}1 \text { - The doubt I had was } \\
\text { because I felt many things, } \\
\text { but I didn't know it was } \\
\text { diabetes. (Participant } 4 \text {, } \\
\text { female, } 74 \text { years old) } \\
2 \text { - At the health center they } \\
\text { give information about } \\
\text { medication and pressure. } \\
\text { (Participant 4, female, } 74 \\
\text { years old) }\end{array}$ & $\begin{array}{l}1 \text { - I didn't know and didn't } \\
\text { even know what the word } \\
\text { diabetes was. (Participant 19, } \\
\text { female, } 61 \text { years old) } \\
2 \text { - The neighbor had surgery } \\
\text { and almost died. I always } \\
\text { visited him and he told me how } \\
\text { the illness started. (Participant } \\
16, \text { male, } 64 \text { years old) }\end{array}$ & $\begin{array}{l}1 \text { - I thought it was a simpler disease, right, } \\
\text { that this little pain in the legs was normal, } \\
\text { the doctor said you could have a stroke. } \\
\text { (Participant 3, female, } 68 \text { years old) } \\
2 \text { - In the health unit, the information was } \\
\text { clear and this has been arousing, because } \\
\text { illness is not a joke. (Participant 5, female, } \\
61 \text { years old) }\end{array}$ \\
\hline
\end{tabular}


Chart 2 - Presentation of themes and examples of participants' statements, referring to category Ability to understanding health information, at baseline and follow-up, Arapiraca, Alagoas, Brazil, 2018

\begin{tabular}{|c|c|c|c|}
\hline \multicolumn{4}{|c|}{ Category: Ability to understanding health information } \\
\hline CG* baseline themes & CG* follow-up themes & IGt baseline themes & IGt follow-up themes \\
\hline $\begin{array}{l}\text { What they did when they did not } \\
\text { understand a medical term: } 1 \text { - most } \\
\text { reported doing nothing when they do } \\
\text { not understand the information; } 2 \text { - some } \\
\text { mentioned asking family and friends; } 3 \text { - } \\
\text { the others mentioned asking the doctor. }\end{array}$ & $\begin{array}{l}\text { What they did when they did } \\
\text { not understand a medical } \\
\text { term: similar to the baseline } \\
\text { (except item 2, which was not } \\
\text { mentioned) }\end{array}$ & $\begin{array}{l}\text { What they did when they did } \\
\text { not understand a medical } \\
\text { term: } 1 \text { - reported doing } \\
\text { nothing when they do not } \\
\text { understand the information; } \\
2 \text { - some reported trying to } \\
\text { understand on their own }\end{array}$ & $\begin{array}{l}\text { What they did when they did } \\
\text { not understand a medical term: } \\
1 \text { - reported doing nothing when } \\
\text { they do not understand the } \\
\text { information; } 2 \text { - related the lack of } \\
\text { understanding to aspects of aging. }\end{array}$ \\
\hline \multicolumn{4}{|c|}{ Examples of participants' speeches } \\
\hline $\begin{array}{l}1 \text { - I didn't ask why I was embarrassed, } \\
\text { because the person would think I was } \\
\text { stupid. (Participant } 10 \text {, male, } 73 \text { years old) } \\
2 \text { - I asked my wife. (Participant 11, male, } \\
63 \text { years old) } \\
3 \text { - I asked again. (Participant 14, female, } \\
62 \text { years old) }\end{array}$ & $\begin{array}{l}1 \text { - I don't ask or ask the person } \\
\text { to explain again. (Participant 2, } \\
\text { male, } 67 \text { years old) } \\
3 \text { - Occasionally he said a word I } \\
\text { didn't understand, I asked again } \\
\text { to clear up the doubt. (Participant } \\
7, \text { female, } 61 \text { years old) }\end{array}$ & $\begin{array}{l}1 \text { - I stay quiet not } \\
\text { understanding, not to disturb. } \\
\text { (Participant } 3 \text {, female, } 68 \text { years } \\
\text { old) } \\
2 \text { - There are things that I go after } \\
\text { and want to know. (Participant } 8 \text {, } \\
\text { female } 61 \text { years old) }\end{array}$ & $\begin{array}{l}1 \text { - I don't ask again, I keep } \\
\text { thinking to myself. (Participant } \\
\text { 10, female, } 63 \text { years old) } \\
2 \text { - Lately I even have vision } \\
\text { problems, I don't hear well and I } \\
\text { don't understand. (Participant 3, } \\
\text { female, } 68 \text { years old) }\end{array}$ \\
\hline
\end{tabular}

Chart 3 - Presentation of themes and examples of participants' statements, referring to category Ability to sharing health information, at baseline and follow-up, Arapiraca, Alagoas, Brazil, 2018

\begin{tabular}{|c|c|c|c|}
\hline \multicolumn{4}{|c|}{ Category: Ability to communicating/sharing health information } \\
\hline CG* baseline themes & CG* follow-up themes & IGt baseline themes & IGt follow-up themes \\
\hline $\begin{array}{l}\text { Information that would be } \\
\text { shared with other elderly: } 1 \text { - } \\
\text { search for a doctor; } 2 \text { - have healthy } \\
\text { habits; } 3 \text { - pray and have faith; } 4 \text { - be } \\
\text { careful with the disease; } 5 \text { - seek } \\
\text { complementary practices. }\end{array}$ & $\begin{array}{l}\text { Information that would be } \\
\text { shared with other elderly: } \\
\text { similar to the baseline } \\
\text { (except item 3, which was not } \\
\text { mentioned) }\end{array}$ & $\begin{array}{l}\text { Information that would be shared } \\
\text { with other elderly: } 1 \text { - take care } \\
\text { not to worsen the health situation; } \\
2 \text { - have healthy habits; } 3 \text { - look for } \\
\text { a specialist doctor; } 4 \text { - some did not } \\
\text { know what to suggest. }\end{array}$ & $\begin{array}{l}\text { Information that would be } \\
\text { shared with other elderly: } 1 \text { - } \\
\text { seek health information; } 2 \text { - look } \\
\text { for a doctor; } 3 \text { - have a healthy diet; } \\
4 \text { - follow drug treatment. }\end{array}$ \\
\hline \multicolumn{4}{|c|}{ Examples of participants' statements } \\
\hline $\begin{array}{l}1 \text { - See a doctor for treatment. } \\
\text { (Participant 3, male, } 68 \text { years old) } \\
2 \text { - Do not eat too much salt or fatty } \\
\text { foods. (Participant } 4 \text {, female, } 74 \\
\text { years old) } \\
3 \text { - Wait for God, have faith. } \\
\text { (Participant } 9 \text {, female, } 62 \text { years old) } \\
4 \text { - I would say that he should } \\
\text { take care of himself, because he is } \\
\text { getting old. (Participant 2, male, } 67 \\
\text { years old) } \\
5 \text { - I give advice and the herbs } \\
\text { I have, such as Mororó, Aroeira, } \\
\text { Jatobá... (Participant 10, male, } 73 \\
\text { years old) }\end{array}$ & $\begin{array}{l}1 \text { - So you try to go to the doctor } \\
\text { first, because we have to go, } \\
\text { right? (Participant } 6 \text {, female, } 61 \\
\text { years old) } \\
2 \text { - To do the regimens and } \\
\text { exercises you neeed. (Participant } \\
14 \text {, female, } 62 \text { years old) } \\
3 \text { - I think they should take care } \\
\text { of themselves and measure the } \\
\text { pressure. (Participant } 5 \text {, female, } \\
69 \text { years old) } \\
4 \text { - Herbal tea and natural remedy } \\
\text { is very good. (Participant } 10, \\
\text { male, } 73 \text { years old) }\end{array}$ & $\begin{array}{l}1 \text { - You have to move, do some } \\
\text { physical activity, not to get worse. } \\
\text { (Participant 13, female, } 81 \text { years } \\
\text { old) } \\
2 \text { - If you follow the diet hard and } \\
\text { take the drugs, you can control } \\
\text { it, but no one can control it. } \\
\text { (Participant } 7 \text {, male, } 62 \text { years old) } \\
3 \text { - Going to a specialist doctor, } \\
\text { which is very difficult for those } \\
\text { who don't have a lot of money. } \\
\text { (Participant } 6 \text {, female, } 73 \text { years old) } \\
4 \text { - I don't know, because I } \\
\text { didn't receive any information. } \\
\text { (Participant } 15, \text { male, } 78 \text { years old). }\end{array}$ & $\begin{array}{l}1 \text { - Look for the health center, ask } \\
\text { the right people for information. } \\
\text { (Participant 1, female } 65 \text { years old) } \\
2 \text { - The doctor will give the solution } \\
\text { for this type of problem. (Participant } \\
20 \text {, male, } 76 \text { years old) } \\
3 \text { - Be careful with food, be careful } \\
\text { with salt. Which is what l'm doing } \\
\text { after the group. (Participant } 6 \text {, female, } \\
73 \text { years old) } \\
4 \text { - Each organism works differently } \\
\text { and what works for one doesn't work } \\
\text { for another. You cannot stop taking } \\
\text { the medicine. (Participant } 8 \text {, female, } \\
61 \text { years old) }\end{array}$ \\
\hline
\end{tabular}

${ }^{*} \mathrm{CG}=$ Comparison Group; + IG $=$ Intervention Group.

Chart 4 - Presentation of themes and examples of participants' statements regarding the ability to assess health information, at baseline and follow-up, Arapiraca, Alagoas, Brazil, 2018

\begin{tabular}{|c|c|c|c|}
\hline \multicolumn{4}{|c|}{ Category: Ability to assess health information } \\
\hline CG baseline themes & CG follow-up themes & IG baseline themes & IG follow-up themes \\
\hline $\begin{array}{l}\text { Impact of health information } \\
\text { on participants' lives: } 1 \text { - they } \\
\text { reported changes in the care for } \\
\text { the disease; } 2 \text { - some reported not } \\
\text { making a difference in life; } 3 \text { - for } \\
\text { others, it made a difference }\end{array}$ & $\begin{array}{l}\text { Impact of health information } \\
\text { on participants' lives: similar to } \\
\text { the baseline }\end{array}$ & $\begin{array}{l}\text { Impact of health information } \\
\text { on participants' lives: } 1 \text { - they } \\
\text { reported changes in care for the } \\
\text { disease; } 2 \text { - some reported not } \\
\text { making a difference in life; } 3 \text { - } \\
\text { changes in food. }\end{array}$ & $\begin{array}{l}\text { Impact of health information on } \\
\text { participants' lives: } 1 \text { - they reported } \\
\text { changes to healthy habits; } 2 \text { - increased } \\
\text { knowledge about the chosen health } \\
\text { situation; } 3 \text { - changes in disease care }\end{array}$ \\
\hline
\end{tabular}




\begin{tabular}{|c|c|c|c|}
\hline \multicolumn{4}{|c|}{ Category: Ability to assess health information } \\
\hline \multicolumn{4}{|c|}{ Examples of participants' statements } \\
\hline $\begin{array}{l}1 \text { - Because it's a reason for me to } \\
\text { be more careful with my health. } \\
\text { (Participant } 8 \text {, female, } 69 \text { years old) } \\
2 \text { - I didn't improve anything, it } \\
\text { didn't solve my health problem. } \\
\text { (Participant 7, female, } 61 \text { years old) } \\
3 \text { - They made a difference for the } \\
\text { better, right? (Participant 3, male, } \\
68 \text { years old) }\end{array}$ & $\begin{array}{l}1 \text { - Mainly taking care of your food, } \\
\text { going for a walk. (Participant 12, } \\
\text { female, } 63 \text { years old) } \\
2 \text { - Very little. Because I don't do } \\
\text { physical activity, right? (Participant } \\
7 \text {, female, } 61 \text { years old) } \\
3 \text { - Relieved a little worry about the } \\
\text { disease. (CG Participant 6, female, } \\
61 \text { years old) }\end{array}$ & $\begin{array}{l}1 \text { - The guidelines on how to } \\
\text { carry out the treatment made a } \\
\text { difference. (Participant 14, female, } \\
60 \text { years old) } \\
2 \text { - No, I'm used to not receiving } \\
\text { information. Life goes on with its } \\
\text { problems. (Participant 3, female, } \\
68 \text { years old) } \\
3 \text { - I can no longer eat everything } \\
\text { I could eat. (Participant 19, } \\
\text { female, } 61 \text { years old) }\end{array}$ & $\begin{array}{l}1 \text { - I started to eat differently, every } \\
\text { day I make salad and I try to exercise. } \\
\text { (Participant 5, female, } 61 \text { years old) } \\
2 \text { - Before I had the problem and } \\
\text { didn't know what it was, now I } \\
\text { know how to deal with my disease. } \\
\text { (Participant 10, female, } 63 \text { years old) } \\
3 \text { - When the information is good, it } \\
\text { makes a difference, in the medication, } \\
\text { I didn't stop anymore. (Participant 8, } \\
\text { female, } 61 \text { years old) }\end{array}$ \\
\hline
\end{tabular}

${ }^{*} \mathrm{CG}=$ Comparison Group; $+\mid \mathrm{G}=$ Intervention Group.

In Chart 3, about the information that participants would share with other elderly people, it was observed that the information had a basic character and little development of content.

Chart 4 refers to category Ability to assess health information. Most participants from both groups reported the impact of information on health, but were unable to describe in-depth the changes generated in health.

\section{DISCUSSION}

Considering participants' sociodemographic data, most of the elderly were female, lived accompanied, had few years of education and low income, corroborating a study that presented the profile of elderly people in a community in northeastern Brazil(27).

The interaction of SAHLPA score means had a slight increase in both groups after the intervention, with no statistical significance. Even after Alpha-Health, most participants continued with inadequate health literacy, although there was an increase in the proportion of elderly people with adequate health literacy. Intervention studies that used other health literacy assessment instruments were identified and demonstrated the increase in health literacy scores in adults with high education in Japan ${ }^{(28)}$ and in adults with low education in Australia ${ }^{(29)}$.

As for the increase in the proportion of elderly people with adequate health literacy, especially in the IG, the result was still lower than the proportion found in category Adequate health literacy (43.4\%) in a Brazilian study with a cross-sectional design carried out with elderly diabetics from an outpatient clinic in São Paulo(14).

The relationship between health literacy and health habits was also verified in a previous study ${ }^{(30)}$. Another investigation found a positive association between elderly people with higher health literacy and who received the influenza and/or pneumococcus vaccine $^{(31)}$. After the intervention, participants developed health literacy skills to access and use a vaccination service that was available at the health facility.

Health professionals are important providers of health information and need to know strategies to reduce health literacy demands through effective interpersonal communication, health materials in written and visual formats, and creating environments that improve care delivery ${ }^{(32)}$. It should be noted, however, that professional nurses from the health units were not mentioned at any time as a source of information or as a reference professional at baseline. This finding leads to reflection on a doctor-centered care and on how the nursing care developed is having an impact on elderly's lives in communities.

It was observed that participants had difficulties in understanding terms from the SAHLPA, as found in a study ${ }^{(29)}$, who interviewed adults with inadequate health literacy and who had difficulty reading and understanding the meaning of health terms. The absence of changes can be related to numerous factors, such as low education or the physical, cognitive and psychological changes of aging that can compromise learning. The reduced development of this skill can have repercussions in chronic disease management. Thus, health professionals must be aware of the difficulties of elderly users and direct care according to each person's specificities using various tools to improve communication and understanding of health information.

Studies assessing the demand for health care show that inadequate health literacy can have negative psychological effects, since individuals may feel intimidated or anxious ${ }^{(33)}$, impairing interaction and communication with caregivers ${ }^{(34)}$.

It was observed that the elderly were at the functional level of health literacy ${ }^{(2)}$, with little criticism and reflection on how to deal with health information and not knowing what to suggest for other elderly people. Others resorted to religion and complementary practices to indicate to other elderly people, meeting the results of a Brazilian study ${ }^{(35)}$, in which the elderly relied on the use of teas, medicinal herbs and home care practices. It is possible that these practices are part of their daily lives, however, the fact that the elderly, in some cases, rely on and share popular information and not on information provided by caregivers is concerned.

After Alpha-Health, the elderly in the IG seem to have given greater importance to the search for health information and it was clear to them that the information useful for some might not be useful for others, which demonstrates the importance of care for each individual, confirming the result of a study with adults and the elderly in Ireland(36).

In data triangulation, the ability to access health information seemed to reflect what was learned during Alpha-Health, which may be related to the improvement of health habits. Access to the Basic Health Unit and the importance of information from it impacts on better vaccination adherence, with statistically significant results.

With regard to the comprehension skill, although SAHLPA only assesses the reading and association of terms in the health area, 
in the interaction of the quantitative score or in the qualitative results, demonstrations of changes in this skill were not observed in participants' reports, being a result that remained unchanged and converged in the present study.

Even without statistical significance, there was an increase in health literacy scores (SAHLPA-18), which was also noticeable in the qualitative stage. There was an improvement in the performance of elderly's health literacy skills, since they were more confident and empowered (considering the starting point) to deal with the information and the health situation, supporting the study ${ }^{(28)}$, who also noted the development of health literacy skills in quantitative and qualitative results.

\section{Study limitations}

This study has limitations, the main one being the number of losses (more than expected), which may be justified by the long period of time of the intervention, which may have impaired the elderly's participation. Considering that the SAHLPA score words were mentioned during the intervention, this increase was expected, which may be related to previous learning difficulties in childhood and/or related to the cognitive decline of aging. Furthermore, the instrument for assessing health literacy, SAHLPA, considered the best choice among the instruments already validated in Brazil, may not have been the most suitable for the assessment of a vulnerable population, with low education, such as participants. There is still a scarcity of studies that carried out interventions with the elderly and that had health literacy as an outcome, making it difficult to compare the results.

\section{Contributions to nursing}

The Alpha-Health intervention proved to be an important device for the development of elderly's health literacy as well as for changing elderly's habits in a community. These results have implications in practice, especially in care strategies, with an emphasis on the elderly's role and on the potential for formulating and structuring health education activities in PHC.

The implementation of health literacy programs with elderly groups can encourage the development of skills necessary for autonomy, chronic condition management and elderly's knowledge. Interventions of this type contribute to the link between elderly and nurses, as well as becoming an important source of health information, focused on the qualification of nursing care in PHC.

\section{CONCLUSION}

The Alpha-Health intervention improved health literacy scores, although without statistical significance. Health habits such as having vaccinations, three meals a day and eating meat improved statistically significantly. The development of health literacy skills could be seen in the final assessment of the qualitative results, with elderly people relatively more confident and critical in relation to the search, communication and assessment of health information. In data triangulation, convergence was verified by the improvement of health habits and by the increase in knowledge about health and self-care. The ability to understand health information remained similar at baseline and follow-up, possibly related to elderly's socioeconomic aspects.

For future studies, it is suggested to investigate elderly Brazilians in different contexts, those with low education, the illiterate and even the elderly with a higher level of education. It is important to explore the barriers and potential to promote health literacy, the development of interventions and new devices, including methodologies that enhance health literacy skills and the exchange of information between the elderly and caregivers.

\section{ACKNOWLEDGMENT}

This work was carried out with the support of the Brazilian National Council for Scientific and Technological Development (CNPq - Conselho Nacional de Desenvolvimento Científico e Tecnológico).

\section{SUPPLEMENTARY MATERIAL}

Serbim AK, Paskulin LMG. Efeitos de uma intervenção educativa na alfabetização em saúde de idosos na atenção primária. 2020. Tese (Doutorado em Enfermagem). Universidade Federal do Rio Grande do Sul. Available from: http://hdl.handle.net/10183/219849.

\section{REFERENCES}

1. Trezona A, Rowlands G, Nutbeam D. Progress in implementing National policies and strategies for health literacy: what have we learned so far? Int J Environ Res Public Health. 2018;15(7). https://doi.org/10.3390/ijerph15071554

2. Nutbeam D. Health literacy as a public health goal: a challenge for contemporary health education and communication strategies into the 21st century. Health Promot Int. 2000;15(3):259-67. https://doi.org/10.1093/heapro/15.3.259

3. Sorensen K, Van Den Broucke S, Fullam J, Doyle G, Pelikan J, Slonska Z, et al. Health literacy and public health: a systematic review and integration of definitions and models. BMC Public Health. 2012;12(1):80. https://doi.org/10.1186/1471-2458-12-80

4. Begoray DL, Kwan B. A Canadian exploratory study to define a measure of health literacy. Health Promot Int. 2012;27(1):23-32. https://doi. org/10.1093/heapro/dar015

5. Sorensen K, Pelikan JM, Röthlin F, Ganahl K, Slonska Z, Doyle G, et al. Health literacy in Europe: comparative results of the European health literacy survey (HLS-EU). Eur J Public Health. 2015;25(6):1053-8. https://doi.org/10.1093/eurpub/ckv043

6. Berkman ND, Sheridan SL, Donahue KE, Halpern DJ, Crotty K. Low Health Literacy and Health Outcomes: An Updated Systematic Review. Ann Intern Med. 2011;155(2):97-107. https://doi.org/10.7326/0003-4819-155-2-201107190-00005 
7. Hardie N, Kyanko K, Busch S, Losasso A, Levin R. Health Literacy and Health Care Spending and Utilization in a Consumer-Driven Health Plan. J Health Commun. 2011;16(3):308-21. https://doi.org/10.1080/10810730.2011.604703

8. Bostock S, Steptoe A. Association between low functional health literacy and mortality in older adults: longitudinal cohort study. BMJ. 2012;344:e1602. https://doi.org/10.1136/bmj.e1602

9. Carthery-Goulart MT, Anghinah R, Areza-Fegyveres R, Bahia VS, Brucki SMD, Damin A, et al. Performance of a Brazilian population on the test of functional health literacy in adults. Revista de Saúde Pública. 2009; 43(4):631-8. https://doi.org/10.1590/\$0034-89102009005000031

10. Rodrigues R, de Andrade SM, González AD, Birolim MM, Mesas AE. Cross-cultural adaptation and validation of the Newest Vital Sign (NVS) health literacy instrument in general population and highly educated samples of Brazilian adults. Public Health Nutr. 2017;20(11):1907-13. https://doi.org/10.1017/S1368980017000787

11. Borges FM, Silva ARV da, Lima LH de O, Almeida PC de, Vieira NFC, Machado ALG. Health literacy of adults with and without arterial hypertension. Revista Brasileira de Enfermagem. 2019;72(3):646-53. https://doi.org/10.1590/0034-7167-2018-0366

12. Martins NFF, Abreu DPG, Silva BT, Bandeira EDO, Lima JP de, Mendes JM. Functional literacy on health of elderly people in a family health unit. Rev Enferm do Cent Oeste Min. 2019;9:1-10. https://doi.org/10.19175/recom.v9i0.2937

13. Apolinario D, Braga R de COP, Magaldi RM, Busse AL, Campora F, Brucki S, et al. Short Assessment of Health Literacy for Portuguese-speaking Adults. Revista de Saúde Pública 2012;46(4):702-11. https://doi.org/10.1590/S0034-89102012005000047

14. Souza JG, Apolinario D, Magaldi RM, Busse AL, Campora F, Jacob-Filho W. Functional health literacy and glycaemic control in older adults with type 2 diabetes: a cross-sectional study. BMJ Open. 2014;4(2):e004180-e004180. https://doi.org/10.1136/bmjopen-2013-004180

15. Coll-Planas L, Blancafort S, Rojano X, Roqué M, Monteserín R. Promoting self-management, health literacy and social capital to reduce health inequalities in older adults living in urban disadvantaged areas: protocol of the randomised controlled trial AEQUALIS. BMC Public Health. 2018;18(1):345. https://doi.org/10.1186/s12889-018-5219-x

16. Manafo E, Wong S. Health literacy programs for older adults: a systematic literature review. Health Educ Res. 2012;27(6):947-60. https://doi. org/10.1093/her/cys067

17. Des Jarlais DC, Lyles C, Crepaz N, Group T. Improving the reporting quality of nonrandomized evaluations of behavioral and public health interventions: the TREND statement. Am J Public Health. 2004;94(3):361-6. https://doi.org/10.2105/ajph.94.3.361

18. Instituto Brasileiro de Geografia e Estatística (IBGE). Brasil/Alagoas/Arapiraca. Panorama [Internet]. 2019 [cited 2019 Dec 20]. Available from: https://cidades.ibge.gov.br/brasil/al/arapiraca/panorama

19. Apolinario D, Lichtenthaler D, Magaldi R, Soares A, Busse A, Amaral J, et al. Using temporal orientation, category fluency, and word recall for detecting cognitive impairment: the 10-point cognitive screener (10-CS). Int J Geriatr Psychiatry. 2015;31(1):4-12. https://doi.org/10.1002/gps.4282

20. Paskulin LMG, Aires M, Valer DB, De Morais EP, De Almeida Freitas IB. Adaptation of an instrument to measure health literacy of older people. Acta Paul Enferm. 2011;24(2):271-7. https://doi.org/10.1590/S0103-21002011000200018

21. Brasil. Ministério da Saúde. Caderneta de saúde da pessoa idosa. In: Ministério Da Saúde, organizador. Ministério da Saúde [Internet]. 4a. Brasília - DF; 2017 [cited 2019 Dec 20]. 60 p. Available from: https://portalarquivos2.saude.gov.br/images/pdf/2017/setembro/27/ CADERNETA-PESSOA-IDOSA-2017-Capa-miolo.pdf 40.

22. Serbim AK, Paskulin LMG, Nutbeam D. Improving health literacy among older people through primary health care units in Brazil: fearsibility study. Health Promot Int. 2019;daz121. https://doi.org/10.1093/heapro/daz121

23. Organização Mundial da Saúde. Envelhecimento ativo: uma política de saúde. BRASílIA - DF; 2005. 62 p. Available from: https://bvsms. saude.gov.br/bvs/publicacoes/envelhecimento_ativhttps://bvsms.saude.gov.br/bvs/publicacoes/envelhecimento_ativo.pdfo.pdf

24. Guimarães LSP, Hirakata VN. Use of the generalized estimating equation model in longitudinal data analysis. Rev HCPA [Internet]. 2012[cited 2019 Dec 20];32(4):503-11. Available from: https://seer.ufrgs.br/hcpa/article/view/36971/23993

25. Minayo MC de S. O desafio do conhecimento: pesquisa qualitativa em saúde. 9a. São Paulo: Hucitec; 2006. 406 p.

26. Oliveira JLC, Magalhães AMM, Misue-Matsuda L. Mixed methods in nursing research: application possibilities according to Creswell. Texto Contexto Enferm. 2018;27(2):1-8. https://doi.org/10.1590/0104-070720180000560017

27. Sousa FDJD, Gonçalves LHT, Paskulin LGM, Gamba MA. Sociodemographic profile and social support of elderly persons in primary care. Rev Enferm UFPE. 2018;12(4):824. https://doi.org/10.5205/1981-8963-v12i4a22855p824-831-2018

28. Ishikawa H, Yamaguchi I, Nutbeam D, Kato M, Okuhara T, Okada M, et al. Improving health literacy in a Japanese community population: a pilot study to develop an educational programme. Health Expect. 2018;21(4):814-21. https://doi.org/10.1111/hex.12678

29. Muscat DM, Morony S, Shepherd HL, Smith SK, Dhillon HM, Trevena L, et al. Development and field testing of a consumer shared decisionmaking training program for adults with low literacy. Patient Educ Couns. 2015;98(10):1180-8. https://doi.org/10.1016/j.pec.2015.07.023

30. Aaby A, Friis K, Christensen B, Rowlands G, Maindal HT. Health literacy is associated with health behaviour and self-reported health: a large population-based study in individuals with cardiovascular disease. Eur J Prev Cardiol. 2017;24(17):1880-8. https://doi. org/10.1177/2047487317729538

31. Bennett IM, Chen J, Soroui JS, White S. The contribution of health literacy to disparities in self-rated health status and preventive health behaviors in older adults. Ann Fam Med. 2009;7(3):204-11. https://doi.org/10.1370/afm.940 
32. Rajah R, Ahmad Hassali MA, Jou LC, Murugiah MK. The perspective of healthcare providers and patients on health literacy: a systematic review of the quantitative and qualitative studies. Perspect Public Health. 2017;138(2):122-32. https://doi.org/10.1177/175791391773377547.

33. Wolf MS, Williams M V, Parker RM, Parikh NS, Nowlan AW, Baker DW. Patients' shame and attitudes toward discussing the results of literacy screening. J Health Commun. 2007;12(8):721-32. https://doi.org/10.1080/10810730701672173

34. Easton P, Entwistle VA, Williams B. How the stigma of low literacy can impair patient-professional spoken interactions and affect health: insights from a qualitative investigation. BMC Health Serv Res. 2013;13(1):319. https://doi.org/10.1186/1472-6963-13-319

35. Romero SS, Scortegagna HM, Doring M. Functional health literacy level and behavior in the health of the elderly. Texto Context Enferm. 2018;27(4):1-12. https://doi.org/10.1590/0104-07072018005230017

36. McKenna VB, Sixsmith J, Barry MM. A qualitative study of the development of health literacy capacities of participants attending a communitybased cardiovascular health programme. Int J Environ Res Public Health. 2018;15(6):1-19. https://doi.org/10.3390/ijerph15061157 